\title{
IMPACT OF SELECTED CHARACTERISTICS OF SMES ON THE CAPITAL STRUCTURE
}

\author{
Jaroslav BELAS ${ }^{1}$, Beata GAVUROVA ${ }^{2 *}$, Peter TOTH $^{3}$ \\ ${ }^{1}$ Tomas Bata University in Zlín, Faculty of Management and Economics, \\ Zlin, Czech Republic \\ ${ }^{2}$ Department of Banking and Investment, Faculty of Economics, \\ Technical University of Košice, Košice, Slovak Republic \\ ${ }^{3}$ Department of Finance, Faculty of Economics, Technical University of Košice, \\ Košice, Slovak Republic
}

Received 26 July 2018; accepted 14 October 2018

\begin{abstract}
The optimal capital structure is a key precondition for business, even though defining the optimal capital structure is difficult. The available studies present many different and mutually contradictory factors that need to be taken into account in the strategic financial decisions of managers. Their importance and intensity are different for individual business entities. Given the specificities of companies in the SME segment, achieving an optimal capital structure is a challenging task as there is no model of an optimal capital structure that can be universally applied in corporate practice. For this reason, we decided to realize our research. The main aim of the paper is to identify determinants of the SME's capital structure. We studied the impact of four determinants: region, business area, number of employees and business duration, on the manager's decisions about capital structure in the enterprise. Our research is based on the database 'Albertina', which consist of all SME in the Czech Republic. We applied ordinal logistic regression and estimated five models. These models were used to predict attitude of SME to the capital structure. Analysis was done in R Software. The main finding is that the size of the company measured by the number of employees effects its attitude to volume of foreign and own capital used to finance its activities. Analysis also showed that entrepreneurs with longer duration of taking their business prefer more foreign capital than their own capital. Business area and region where enterprise is located do not significantly affect capital structure.
\end{abstract}

Keywords: capital structure, SMEs, company indebtedness, credit risk, loan availability, company prosperity, optimal capital structure, ordinal logistic.

JEL Classification: G32, L26, L53.

${ }^{\star}$ Corresponding author. E-mail: beata.gavurova@tuke.sk 


\section{Introduction}

The issue of optimal capital structure and financial stability of assets is one of the key problems of company existence in market economies. Deciding on an optimal capital structure is a very important managerial decision. When accepting it, it is necessary to take into account several facts: the cost of capital for the company, the ownership structure of the company, business area, and so on. In general, equity costs are higher than the costs of foreign capital for the company because the owner's risk is higher than that of the lender. The business owner puts capital into a company for a predetermined period of time, does not secure its return and fully bears business risk. His capital can be lost. The creditor provides the loan for a certain period of time, obtains pre-agreed interest and repayment of the loan is generally secured by the debtor's assets, respectively by the third party guarantee. The net return can be deducted from the business by the owner on the basis to the detriment of the profit, but only after income taxation. Interest paid to the creditor is a part of the company's financial costs, decreasing the reported profit and thus the tax paid. Using foreign capital creates the so-called tax shield. It is important to pay attention to the factors affecting the capital structure in order to set optimal business performance. These include: cash-flow level and stability, company control, ownership structure, dividend policy and inflation rate (Vlachynský et al., 2009, p. 87). Some research shows that the more structured the owner's structure is, the greater the willingness and tolerance of the higher debt. Family businesses tend to have more debt than similar companies with scattered ownership. An interesting fact is that the family companies are fully financed by equity much more than other companies. There is no unambiguous guidance, methodology, capital structure decision to form an optimal capital structure (Kralovič \& Vlachynský, 2011, p. 171, 172). In particular, management decisions about the company's capital structure must take into account the effect of the factors mentioned, which have a different impact on each firm (Giriūnienė \& Giriūnas, 2015; Kozubíková, Homolka, \& Kristalas, 2017). It is the decision of the management which optimal capital structure to choose in their company and which criteria (Leopoulos, Kirytopoulos, \& Malandrakis, 2006). Available studies and financial professionals have been addressing the issue of optimal capital structure and defining its rules for a long time (Gavurova, Belas, Kocisova, \& Kliestik, 2017; Kliestikova, Misankova, \& Kliestik, 2017). This raises many discussions, as the financial systems and the business environment in each country are highly heterogeneous, accompanied by external influences from the national and international economic environment (Ključnikov \& Popesko, 2017). Even so, there are the so-called formal vertical funding rules aimed to the regulation of the relationships between own and foreign capital. For the riskier areas of the business, the optimal ratio is $2: 1$, meaning that foreign capital does not exceed half of equity. Some experts recommend to ensure the optimal capital structure thereby that the foreign capital does not exceed the potential liquidation value of the firm. It is possible to find many available options and recommendations in the professional and scientific literature. It is important to properly evaluate, compare and examine the impacts of multiple alternatives on business processes in the company both in the short and long term (Hackbarth, Miao, \& Morellec, 2006).

In these intentions, our research has been motivated to study the impact of selected factors on decision making about the structure of capital in a firm. In the current period of 
growing competition, the importance of maintaining the financial stability of companies in every country is steadily rising.

\section{Overview of research studies}

Many research studies examine the access of companies of varying sizes to the sources of funding and the determinants that affect access to finance (Akhmadeev \& Manakhov, 2015). A large part of the study focuses on the SME segment, which is sensitive to changes in economic processes in every economy (Kurschus, Sarapovas, \& Pilinkiene, 2017; Kliestik, Misankova, Valaskova, \& Svabova, 2018; Balcerzak, Kliestik, Streimikiene, \& Smrčka, 2017). Rahman, Twyeafur Rahman, and Belas (2017) in their study examine the determinants affecting SME and access of SME in the Czech Republic, Slovakia and Hungary. Their database consisted of 15,883 companies, and was obtained from the BEEPS survey managed by the World Bank and the European Bank for Reconstruction and Development. As can be seen from the results of the analysis, micro-enterprises and companies owned and operated by women had a lack of credit from banks and had more financial constraints than men-owned firms. This indicates some gender discrimination in the credit market within advanced European countries (e.g. in Felicio \& Galindo Villardón, 2015) In the case of medium-sized companies, it has been confirmed that innovative businesses have received more loans from banks (Rahman et al., 2017; Tvaronavičienè, 2016). The economic position of SMEs in countries is gradually increasing. According to Rahman et al. (2017), by analysing 76 developed and developing countries, it was found that SMEs provide about $60 \%$ of employment in the manufacturing sector. Small and medium-sized businesses experience banking discrimination because of their opacity (Baños-Caballero, García Teruel, \& Martínez-Solano, 2016). Banks also justify this by not having audited financial statements for SMEs and, in fact, it is problematic for the SME sector to demonstrate the ability to repay loans in the future (Virglerova, Dobes, \& Vojtovic, 2016). Business size can be positively linked to access to funding. Attention is also given to the role of securing credit. Loan securing has a positive impact on the size of credit for all businesses. Rahman et al. (2017) state that not only small but also short-term firms are more vulnerable to limited access to bank finance, which is associated with lower transparency of information. Banks are limited in lending to younger companies, and because of the future, the survival rate of younger companies is much lower than that of older firms. Access to financial resources in the SME segment also positively affects the interest rate. With increasing credit default risk and loan size, the interest rate increases. Kersten, Harms, Liket and Maas (2017) in their theoretical study looked at access to finance in the SME segment in LMIC countries. These SMEs have limited access to finance. Therefore, many governments are focusing their development strategies on interventions related to promoting financial access. The authors draw attention to the fact that SME development programs should focus on those companies that have limited access to credit (e.g. they are intensively focused on $\mathrm{R} \& \mathrm{D}$, private companies with export credits, etc.) in order not to push other sources financing (typically in the case of grant programs used as a cheap source of finance). Authors examine the impact of SME financing on company performance, which increased with company size. As larger businesses can be less financially limited, there is 
some optimal size for companies whose funding support leads to significant performance gains. The benefit of the study is the qualitative appreciation of the effectiveness and efficiency of the financial programs for SMEs. The authors draw attention to the need to use rigorous experimental methods used in microfinance studies to evaluate. They also highlight the importance of examining the impact of SME finance programs on other firms as well as on employees. In their analysis they confirmed the significant positive impact of SME financing on capital investment, company performance and employment, and the impact of these components on company profitability and wages. It is problematic to examine the impact of SME financing on economic development and poverty elimination. The study has the potential to provide input to discuss the main policy implications of their findings. Beck and Demirguc-Kunt (2006) in their research investigated the approach of SMEs to raise financial resources. They were based on their position within the private sector in developed and developing countries. They affirm that small firms have greater growth constraints and have less access to formal sources of external financing, which confirms the insufficient contribution of SMEs to the economic growth of the country. The authors analyse the positions of short-term loans in the firm, especially as regards their renewal, which could bring unfavourable interest rates on new loans. This could negatively affect the company's performance. The conclusions of the study show that there are differences between small and large firms related to the company's ownership structure, its flexibility, and so on. For this reason, it is necessary to carry out a more detailed analysis reflecting a number of changes in financial systems and quantifying their impact on company performance. These results are also followed by the Harc study (2014) aimed at exploring how the company's profitability affects the capital structure of SMEs in Croatia. The study examined 500 Croatian SMEs over the period 2005-2010. Annual reports of companies were used as a source of data. The analysis shows that the relationship between the profitability of the firm and the short-term leverage effect was negative and statistically significant in all the years under review. The relationship between profitability and long-term leverage in all the years under review was neither negative nor statistically significant. The study's conclusions show that Croatian SMEs use profits in particular to reduce their indebtedness because they prefer internal sources of external financing. The development of aspects of small and medium-sized enterprises was repeatedly studied in research of Korcsmáros, Mura, and Šimonová (2017), in intentions of economic freedom Mura, Havierniková, and Machová (2017). Their research samples concerned regional market structures in Slovakia and correlated with more extensive research by other authors. They have found that networking helps significantly in many corporate activities of stakeholders, including business financing. The development of cooperation and the possibility of providing financial resources for their further development are encouraged by innovations (Mura et al., 2017; Svec \& Madlenak, 2017). The results of the study are consistent with the consequences of Pecking order theory. Some authors (e.g. Degryse, Goeij, \& Kappert, 2010) point out that short-term credit is more expensive than long-term, although Croatian SMEs taking advantage of short-term loans to a large extent. This is because of easier access to a short-term loan that does not require collateral, such as long-term loans. In addition, companies favouring undistributed profits as the primary source of funding have a lower potential risk of bankruptcy. Business size can be considered an inverse risk of bankruptcy. 
Irwin and Scott (2010) conducted a survey before the "credit crisis" on a sample of 400 SMEs. Research has confirmed the impact of education on fundraising. Interesting differences were also the gender differences examined in the survey. Men - Managers were more ready to take risks, with women starting to run with less money and looking for a little more funding as soon as business began. The survey confirmed that companies with ethnic minorities, especially black owners, had the greatest difficulty in obtaining funding, and therefore relied heavily on "bootstrapping" as a financial strategy. Attention is also drawn to the use of external advice to help raise bank financing resources. Cooperation with the bank in re-evaluating business plans can also be beneficial in order to better assess the beneficiaries of financial support on the basis of comparative analysis and impact studies. The authors state that one survey is not enough to develop recommendations for policymakers. They point out that many SMEs start their activity only with the personal savings of individuals. The main problem is that many good business ideas are not being realized just because of the small firms' access to finance. Non-bank lending paths through Micro-finance institutions (MFIs), as well as Community Development Finance Institutions (CDFI) or non-bank lending paths and other credit paths to support the realization of forward-looking business proposals from entrepreneurs come to attention for those, who do not have enough resources to start their business and can not attract financial investors. Other possible sources are EU structural Funds. Vojtovič (2016) analyzed how management of SMEs evaluate use of these funds. $\mathrm{He}$ found out that EU Structural Funds are use inefficiently and do not increase competitiveness of SMEs. Mazzarol (2014) uses a longitudinal analysis focused on the financial management of SMEs, with an emphasis on operating capital and cash flow management in his theoretical study. His study is based on the current financial problems of SMEs - only few companies have regularly audited their financial flows from budgets and from normal operations. This resulted in a large share of SMEs showing a lack of financial resources. Most companies also did not have a clear credit policy and many failed to secure a loan. Mazzarol (2014) emphasize the importance of effective financial management of SMEs, particularly in the area of financial flows and working capital. His study is based on the recently published research, that there is a positive relationship between effective cash flow management and working capital and the profitability, survival and growth of SMEs. The author appeals to managers owners of small businesses, in particular, to improve cash flow management and working capital. Attention is given to the role of governments, which should play a more active role in supporting and assisting SMEs and in improving their financial management systems. A key role in this process is also played by professional advisors, accountants. Improving financial management practices in SMEs will help these firms become stronger and more powerful. Berger and Udell (2002) and Berger and Udell (2006) assess the issue of credit availability from a different perspective. According to their study, policies and national financial structures influence the availability of credit through bank lending processes. The authors emphasize the causal chain from politics to financial structures that affect the operation and profitability of various credit technologies used by banks. These technologies have a significant impact on the availability of loans to SMEs. The authors define their concept of financial structure in their study. These include the presence of different types of financial institutions and the conditions under which they operate. Credit technology includes several transaction 
technologies and loan-based processes. The lending infrastructure includes the information environment, the legal, judicial and bankruptcy environment, the social environment and the tax and regulatory environment. This infrastructure affects the legality and profitability of credit granting processes. All these elements can affect the availability of loans to SMEs by affecting the extent to which different credit granting technologies can be legally and profitably exploited. The authors consider the regulatory environment to be an important element that can limit to a certain extent the availability of loans for SMEs, and which is also related to the limited structure of financial institutions.

\section{Aim, data and methodology}

The aim of the paper is to identify determinates which affect capital structure of the SMEs. We assume that based on the characteristics of the SME, it is possible to estimate its capital structure. To reach the goal, we build an ordinal logistic regression model to predict capital structure of the SME according to characteristics describing the SME.

Our dataset consists of two parts. The first part contains four indicators of entrepreneurship: region where entrepreneurship is located, business area, duration of the entrepreneurship existence and its size. We analysed SMEs from Czech Republic from all 14 regions: Zlínský region, Jihomoravský region, Olomoucký region, Moravskoslezský region, Praha region, Pardubický region, Liberecký region, Královehradský region, Středočeský region, Vysočina region, Plzeňský region, Ústecký region, Karlovy Vary region and Jihočeský region. SMEs are divided according to business area to six groups: production, trade, agriculture, construction, transportation and other services. The next indicator is age of the entrepreneurship divided into three levels: less than five years, from five to 10 years and more than 10 years. The last independent variable is size of the entrepreneurship. SMEs are split into three groups according to the number of employees: up to ten employees, from 11 to 50 employees and from 51 to 250 employees. The second part of our dataset is created by five statements connected with credit risk. Manager of the SME had five options of to express his attitude to each statement: absolutely agree (2), agree (1), disinterested attitude (0), disagree $(-1)$, absolutely disagree $(-2)$. We analysed these five statements: (1) Foreign capital (bank credit) is cheaper than the entrepreneurship's capital and therefore I use a bank loan. (2) Foreign capital (bank credit) is less risky than the entrepreneurship's capital and therefore I use a bank loan. (3) Business needs some amount of bank credit, but I think that the entrepreneur should have more own capital than bank loans. (4) Foreign capital should be used primarily to finance circulating capital. (5) The most important source of loan repayment is profit. Entrepreneurs were selected from database 'Albertina', which contains all SME in Czech Republic. Dataset is obtained from questioner with the rate of return 58 per cent.

Our dataset consists of 352 SMEs from all 14 regions of Czech Republic. From Liberecký region come 85 SMEs, the second region is Zlínský region with 71 SMEs. On the other hand, only three SMEs comes from Jihočeský region and Plzeňský region. Most of SMEs operate in trade and other services. Sectors with the lowest number of SMEs are agriculture and transportation. In Figure 1 is showed regional structure of our dataset in more details. 


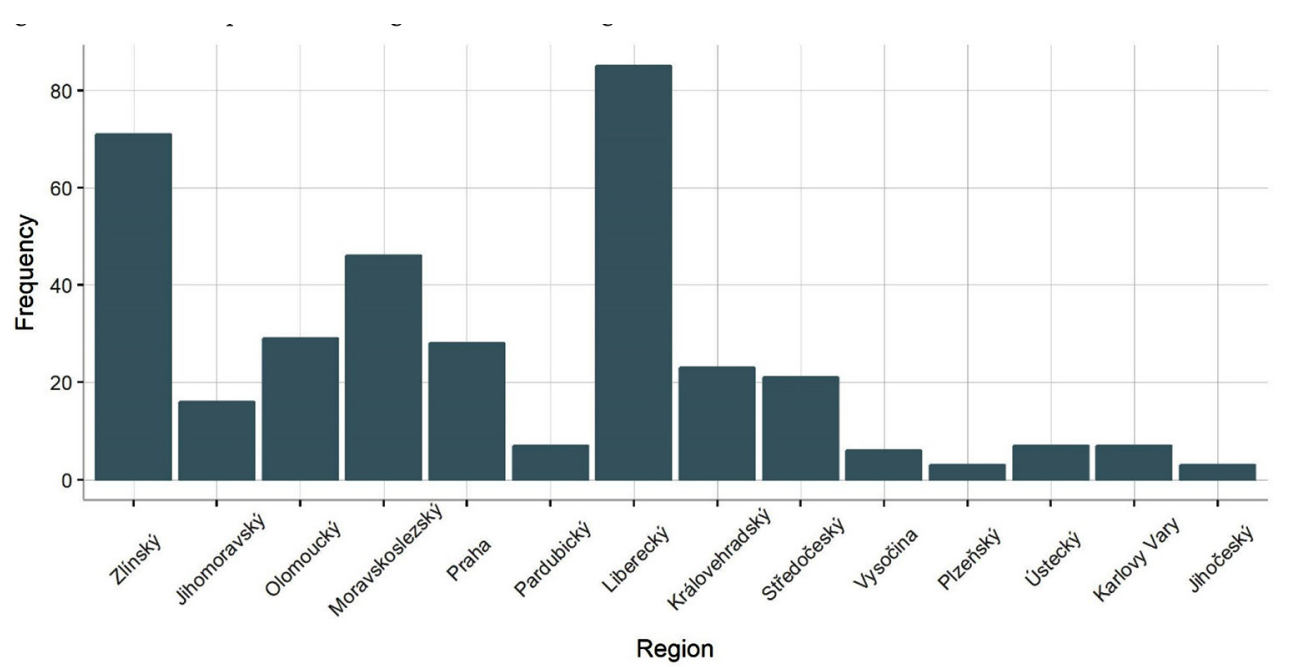

Figure 1. Regional structure of SMEs in dataset

We applied ordinal logistic regression to analyse the impact of specified indicators on the entrepreneur's attitude to credit risk. Ordinal logistic regression is commonly used when dependent variable is ordinal. It is a special case of multinomial regression (Warner, 2008). To estimate model with ordinal dependent variable, cumulative method is commonly used (Bender \& Grouven, 1997). Cumulative probabilities are given by equation (1), where $p_{1}, \ldots$, $p_{i}$ denotes probability of statement and $i=1, \ldots, k$. In our case, dependent variable contains five levels, therefore $k=4$.

$$
P(Y \leq i)=p_{1}+\ldots+p_{i}
$$

Cumulative odds are calculated by expression (2) and cumulative logit is given by equation (3).

$$
\begin{gathered}
\operatorname{odds}(Y \leq i)=\frac{P(Y \leq i)}{1-P(Y \leq i)}=\frac{p_{1}+\ldots p_{i}}{p_{i+1}+\ldots+p_{k+1}} ; \\
\operatorname{logit}(Y \leq i)=\ln \left(\frac{P(Y \leq i)}{1-P(Y \leq i)}\right), \quad i=1, \ldots, k .
\end{gathered}
$$

Our cumulative logistic model is given by equation (4), where $\alpha_{i}, \beta_{1}, \ldots, \beta_{4}$ are logistic coefficients, $X_{1}, \ldots, X_{4}$ are independent variables, $X_{1}$ is region, $X_{2}$ is business area, $X_{3}$ is age and $X_{4}$ denotes size. One model is estimated for each statement.

$$
\operatorname{logit}(Y \leq i)=\alpha_{i}+\beta_{1} X_{1}+\beta_{2} X_{2}+\beta_{3} X_{3}+\beta_{4} X_{4}, \quad i=1, \ldots, k .
$$

\section{Impact of specific indicators on SME's attitude to business financing}

In order to quantify the impact of SME's characteristics, we built five ordinal logistic models, for each statement one. As response variable was used answer of the SME on the statement, which is ordinal variable with five levels. Independent variables are characteristics of SME, specifically region, business area, age and size. Estimated ordinal logistic models are 
presented in Table 1. Estimated model for Statement (1) has statistically significant variable only size. If SME size increase to level 11-50 employees, then the odds of observing answer absolutely disagree vs. observing any other answer will be multiplied by 2.7248 . In the case that SME size is $51-250$, the odds of observing answer absolutely disagree vs. any other answer will increase by $68 \%$. Variables age and business area are not significant. In case of region, there are three regions with p-value lower than 0.1 . According to Table 1 , there is not statistically significant variable in estimated model for Statement (2), only two regions are statistically significant. The third model, for Statement (3), has statistically significant variable size. When SME size is 10-50 employees, the odds that SME choose answer absolutely disagree vs any other answers will be multiplied by 0.4878. In case of SME with 51-250 employees, the chance that SME select answer absolutely disagree vs any other answers will be multiplied by 0.5945 . Moreover, age greater than ten years is statistically significant, as well as three business areas and Jihočeský region.

Table 1. Estimated odds of ordinal logistics models

\begin{tabular}{|c|c|c|c|c|c|c|c|c|c|c|}
\hline \multirow[b]{2}{*}{ Jihomoravský } & \multicolumn{2}{|c|}{ Statement (1) } & \multicolumn{2}{|c|}{ Statement (2) } & \multicolumn{2}{|c|}{ Statement (3) } & \multicolumn{2}{|c|}{ Statement (4) } & \multicolumn{2}{|c|}{ Statement (5) } \\
\hline & 2.1806 & & 1.5359 & & 0.8931 & & 0.8129 & & 0.5965 & \\
\hline Olomoucký & 1.1313 & & 1.8194 & & 1.5047 & & 1.4336 & & 0.8687 & \\
\hline $\begin{array}{l}\text { Moravs- } \\
\text { koslezský }\end{array}$ & 0.9863 & & 1.2409 & & 1.1362 & & 0.5121 & * & 0.7672 & \\
\hline Praha & 1.8087 & & 0.9220 & & 1.3958 & & 0.6024 & & 0.5704 & \\
\hline Pardubický & 3.6755 & * & 0.5691 & & 0.7355 & & 0.3900 & & 0.5389 & \\
\hline Liberecký & 0.9808 & & 1.4844 & & 1.0042 & & 0.4045 & $* * *$ & 0.8335 & \\
\hline $\begin{array}{l}\text { Královeh- } \\
\text { radský }\end{array}$ & 1.2258 & & 1.4312 & & 1.4866 & & 0.8265 & & 0.9997 & \\
\hline Středočeský & 1.3003 & & 1.0883 & & 1.1316 & & 0.7005 & & 0.4615 & \\
\hline Vysočina & 0.2524 & & 0.1283 & $* *$ & 0.3355 & & 0.6553 & & 1.6751 & \\
\hline Plzeňský & 3.3760 & & 1.6261 & & 0.4030 & & 2.9606 & & 1.0964 & \\
\hline Ústecký & 3.3308 & * & 3.9495 & * & 1.7973 & & 0.5398 & & 1.0695 & \\
\hline Karlovy Vary & 4.9106 & $* *$ & 2.5485 & & 0.7183 & & 0.7863 & & 1.1011 & \\
\hline Jihočeský & 0.4675 & & 0.5723 & & 90.4793 & $* * *$ & 1.7030 & & 1.3896 & \\
\hline Trade & 0.7606 & & 0.8016 & & 0.5812 & & 1.8587 & * & 2.1370 & ** \\
\hline Agriculture & 1.0129 & & 1.1036 & & 0.4781 & & 1.0206 & & 1.0974 & \\
\hline Construction & 0.9288 & & 1.3825 & & 0.4928 & * & 0.8424 & & 1.1402 & \\
\hline $\begin{array}{l}\text { Transporta- } \\
\text { tion }\end{array}$ & 2.0146 & & 1.0838 & & 0.2222 & $* *$ & 4.1054 & $* *$ & 0.9912 & \\
\hline $\begin{array}{l}\text { Other ser- } \\
\text { vices }\end{array}$ & 1.1504 & & 1.1213 & & 0.3766 & $* * *$ & 1.4044 & & 1.0936 & \\
\hline $\begin{array}{l}\text { Age 5-10 } \\
\text { years }\end{array}$ & 0.7906 & & 0.7311 & & 1.4240 & & 0.6998 & & 1.1320 & \\
\hline $\begin{array}{l}\text { Age }>10 \\
\text { years }\end{array}$ & 0.7253 & & 1.0248 & & 1.8002 & $* *$ & 0.7238 & & 1.0417 & \\
\hline
\end{tabular}


End of Table 1

\begin{tabular}{|l|c|c|c|c|c|c|c|c|c|c|}
\hline & \multicolumn{2}{|c|}{ Statement (1) } & \multicolumn{2}{|c|}{ Statement (2) } & \multicolumn{2}{c|}{ Statement (3) } & \multicolumn{2}{|c|}{ Statement (4) } & \multicolumn{2}{|c|}{ Statement (5) } \\
\hline $\begin{array}{l}\text { Size 11-50 } \\
\text { empl. }\end{array}$ & 2.7248 & $* * *$ & 1.7114 & & 0.4878 & $* *$ & 0.9308 & & 0.7559 & \\
\hline $\begin{array}{l}\text { Size 51-250 } \\
\text { empl. }\end{array}$ & 1.6857 & $*$ & 1.2481 & & 0.5945 & $*$ & 1.6053 & $*$ & 0.7701 & \\
\hline$-2 \mid-1$ & 0.1076 & $* * *$ & 0.1854 & $* * *$ & 0.0073 & $* * *$ & 0.0418 & $* * *$ & 0.0189 & $* * *$ \\
\hline$-1 \mid 0$ & 0.9885 & & 2.1069 & $*$ & 0.1212 & $* * *$ & 0.4171 & $* *$ & 0.1580 & $* * *$ \\
\hline $0 \mid 1$ & 2.8250 & $* *$ & 7.0604 & $* * *$ & 0.2612 & $* * *$ & 1.7577 & & 0.3711 & $* *$ \\
\hline $1 \mid 2$ & 29.1397 & $* * *$ & 89.9002 & $* * *$ & 3.2488 & $* * *$ & 44.9477 & $* * *$ & 5.5356 & $* * *$ \\
\hline
\end{tabular}

Note: ${ }^{* * *}{ }^{* *},{ }^{\star}$ denote significance levels on 1,5 and 10 percent respectively.

Based on the estimated models, we predict entrepreneur's decisions about capital structure. Only two estimated models contain statistically significant variables, so these models are applied to predictions. The first model is model for Statement (1), which is about the costs of foreign and own capital. The second model used for prediction is model for Statement (3), which is about the share of own and foreign capital.

We predicted answers of SMEs according to selected indicators using models presented above. Figure 2 shows probability that SME selects its attitude to Statement (1). Statistically significant variable for Statement (1) is size. We can see that in case of small entrepreneur with 1-10 employees, the answer with the highest probability is disagree with statement that foreign capital is cheaper than the entrepreneurship's capital and therefore I use a bank loan. That result can be interpreted that small entrepreneurs prefer own capital rather than bank loans. The second most probable answers in case entrepreneurs with up to 10 employees are agree (1) and disinterested attitude (0). Probability of appearance these answers is about $20 \%$. Slightly above $10 \%$ is answer absolutely disagree $(-2)$. Answer with the lowest probability is

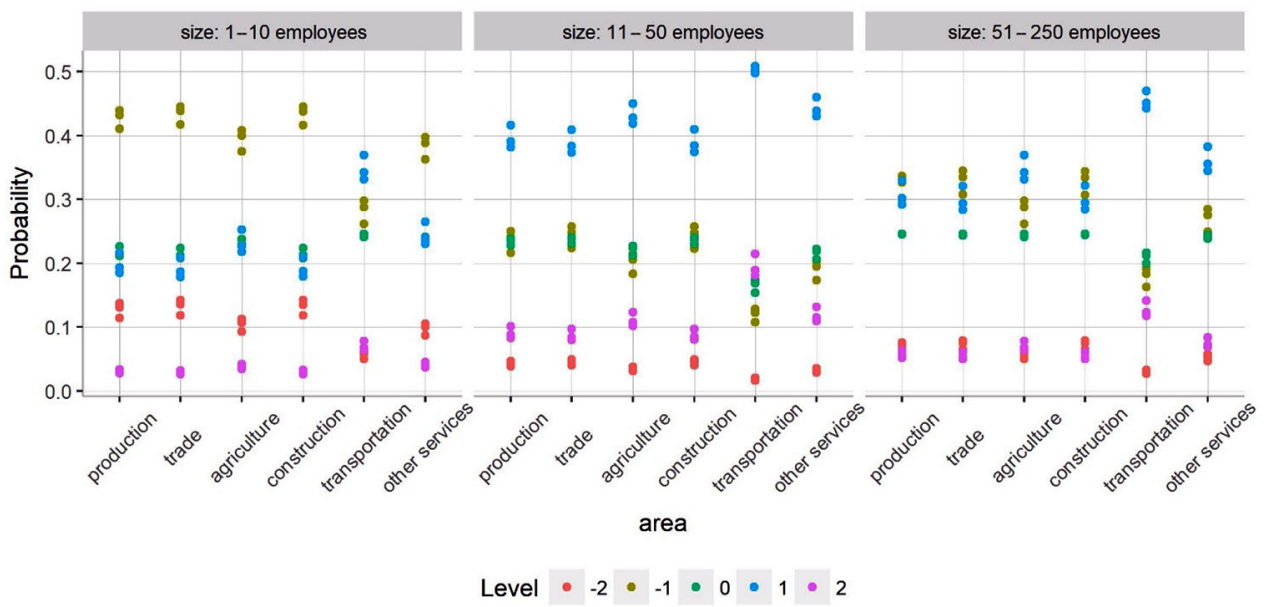

Figure 2. Probability of answers of SMEs for Statement (1) based on the model prediction 
absolutely agree (2). For SME with 11-50 employees, the most probable answer is agree (1) with probability rate about $40 \%$, followed by answers disagree $(-1)$ and disinterested attitude (0) with probability above $20 \%$. Here, we can see, that entrepreneurs with $11-50$ prefer bank loans rather than entrepreneur's capital. In contrast with entrepreneurs with up to 10 employees are also answers absolutely agree (2) and absolutely disagree ( -2$)$. The probability that entrepreneur with 11-50 employees absolutely agree (2) is higher than that entrepreneur absolutely disagree (-2). Different situation is case of entrepreneurs with size 51-250 employees. Answer with the highest probability is not so significant as in the previous cases. Both answers, agree (1) and disagree ( -1$)$, are at the same level of probability, which is about $30 \%$. Then follows answer disinterested attitude (0) with probability $25 \%$. The same situation as in case of answers agree (1) and disagree (-1), is in case of answers absolutely agree (2) and absolutely disagree $(-2)$. Probability of occurrence these answers is approximately $8 \%$. Based on the presented prediction of SME's answer, it seems that entrepreneur with more employees uses more foreign capital, but it is not so obvious for entrepreneurs with 51-250 employees. Figure 2 presents also relationship between entrepreneur's answer and its business area. We can recognize differences among business areas. Specifically, transportation differs from other business areas. According to the prediction, entrepreneurs from that sector consider foreign capital cheaper than their own capital and therefore use foreign capital in case of all sizes of SME. However, variable business area is not statistically significant according to model shown in Table 1 and therefore that relationship is not statistically confirmed. Based on the model shown in Table 1, there are two statistically significant variables for Statement (3): age and size. Prediction of entrepreneur's answer on Statement (3) that business needs some amount of bank credit, but I think that the entrepreneur should have more own capital than bank loans, is presented in Figure 3. In case of entrepreneur with up to ten employees and age lower than five years is the most probable answer disagree (-1) with Statement (1), which means that these entrepreneurs think that they need more bank loans than own capital. Probability of occurrence this answer is about $40 \%$. With probability rate $20 \%$ is followed by answers agree (1) and disinterested attitude (0). Answer absolutely disagree ( -2$)$ should occur with probability $10 \%$ and probability of appearance the answer absolutely agree (2) is less than $5 \%$.

For entrepreneurs with up to ten employees and age from five to ten years is again the most probable answer disagree ( -1 ) with probability rate more than $40 \%$. The second most probable answer is disinterested attitude (0) with probability rate above $20 \%$ followed by answer agree (1) with probability rate nearly $20 \%$. Answer absolutely disagree (-2) has probability rate about $12 \%$ and answer absolutely agree (2) can occur with probability less than $5 \%$.

Similar situation is for entrepreneur with up to ten employees and age more than ten years. Probability of occurrence answer disagree $(-1)$ is around $45 \%$. Then follows answer disinterested attitude (0) with probability of appearance above $20 \%$. On the third place, there is answer agree (1) with probability less than $20 \%$. Answer absolutely disagree ( -2$)$ has probability about $12 \%$ and answer absolutely agree appear with probability less than $5 \%$. To summarize, with the increase in business duration, probability that entrepreneurs with up to ten employees disagree with Statement (3) rise, which means that the longer the entrepreneur business takes, the more preferred foreign capital is. 


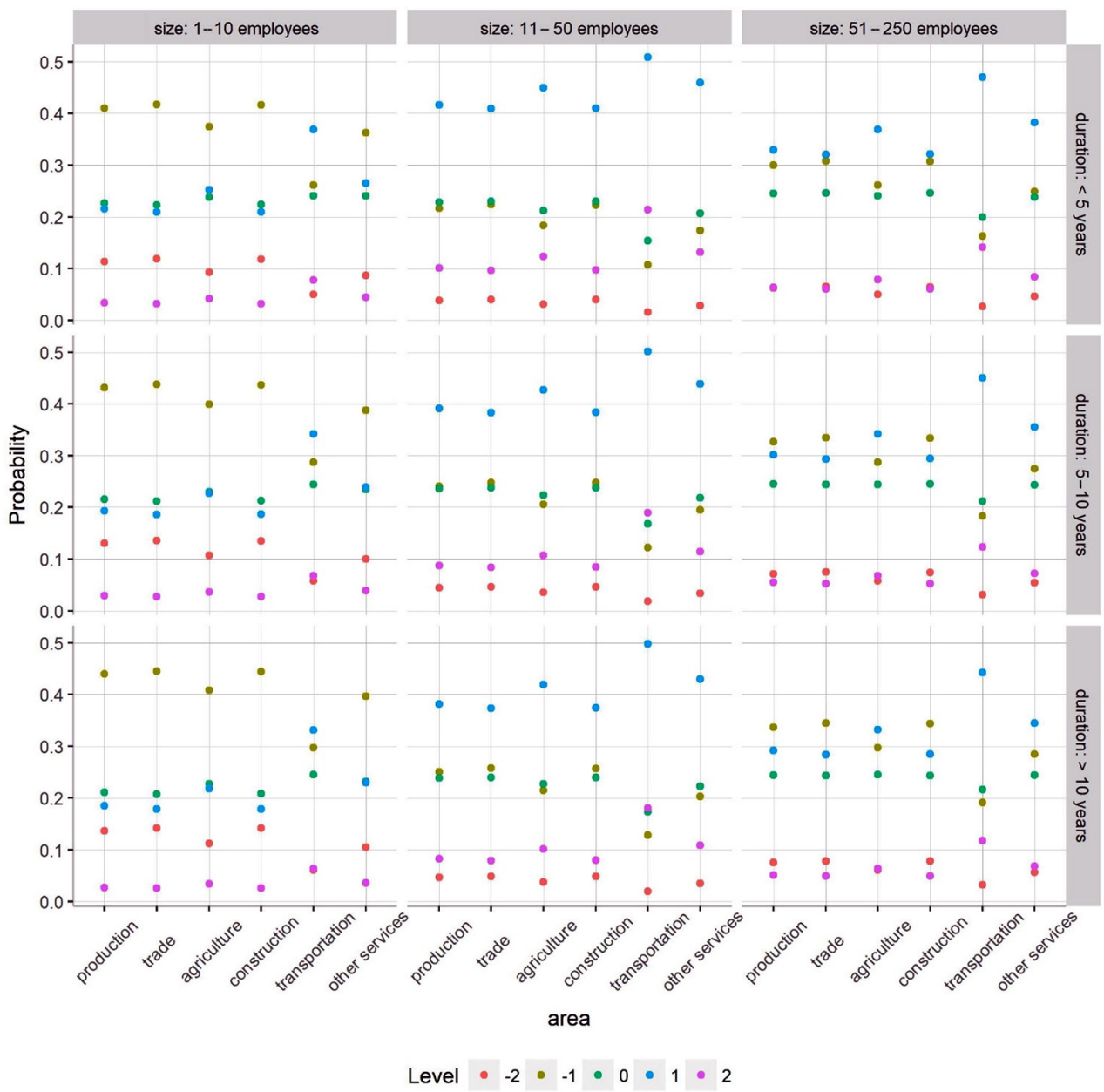

Figure 3. Probability of answers of SMEs for Statement (3) based on the model prediction

In case of entrepreneurs with 11-50 employees and age less than five years, according to the estimated model for Statement (3), answer with the highest probability of appearance is answer agree (1) with probability rate more than $40 \%$. Probability of occurrence answers disinterested attitude (0) and disagree $(-1)$ is above $20 \%$. Then follows answer absolutely agree (2) with probability of occurrence more than $10 \%$. Answer absolutely disagree $(-2)$ is the least probable answer with probability of appearance less than 5\%.

Answer with the highest probability for entrepreneurs with from 11 to 50 employees and age from five to ten years is answer agree (1). Probability rate of the answer agree (1) is around $40 \%$. The second most probable answers are disinterested attitude (0) and disagree $(-1)$ with probability rate about $25 \%$. Answer with the next highest probability of occurrence is absolutely agree (2) with probability rate almost $10 \%$ followed by answer absolutely disagree $(-2)$ with probability rate about $5 \%$. 
If entrepreneurs with 11-50 employees operates its business more than ten years, the most probable answer is agree (1) with probability about $40 \%$. Again, probabilities of appearance answers disinterested attitude (0) and disagree $(-1)$ are very close, approximately $25 \%$. The least probable answers are absolutely agree (2) and absolutely disagree ( -2$)$. Probability that entrepreneur selects answer absolutely agree (2) is almost $10 \%$ and absolutely disagree $(-2)$ is around $5 \%$.

The last size group contains entrepreneurs with from 51 to 250 employees. In this group, there is not so obvious the most probable answer. In case of businesses with duration lower than five years, answer with the highest probability of occurrence is answer agree (1) with probability rate between $30 \%$ and $40 \%$. The second highest probability rate has answer disagree $(-1)$ with probability rate about $30 \%$ followed by answer disinterested attitude (0), which occur with probability $25 \%$. Answer absolutely agree (2) has probability rate about $7 \%$. Similar probability of appearance has answer absolutely disagree $(-2)$.

For entrepreneurs with 51-250 employees and age from five to ten years, probability of occurrence answers agree (1) and disagree (-1) are similarly about $30 \%$. Than follows answer disinterested attitude (0) with probability rate $24 \%$. As well as answers agree (1) and disagree $(-1)$, probability rates of answers absolutely agree (2) and absolutely disagree $(-2)$ are similar, above $5 \%$.

When entrepreneur takes business for more than ten years, differences between probabilities of appearance answers agree (1) and disagree (-1) are again very small. These answers occur with probability rate slightly more than $30 \%$. Probability of occurrence $25 \%$ has answer disinterested attitude (0). Answers absolutely agree (2) and absolutely disagree (-2) are chosen by entrepreneur with probability lower than $10 \%$.

Figure 3 also shows differences among entrepreneurs from different business areas. As well as in case of Statement (1), the most differs transportation area, but variable business area is again statistically significant according to estimated model in Table 1.

According to realized estimation, increase in age of the entrepreneur with up to ten employees leads to the fact, that increase probability of appearance answers disagree $(-1)$ and absolutely disagree (-2) and decrease the probability of answers agree (1) and absolutely agree (2). This means that with higher age of the company, entrepreneurs think that they need more foreign capital than their own capital. The same situation is in case of entrepreneurs with 11-50 employees. But they still rather agree with statement that they need more own capital than foreign capital. Trend of increasing probability of answers disagree ( -1$)$ and absolutely disagree ( -2$)$ is also obvious in case of entrepreneurs with 51-250 employees. Effect of entrepreneur's size measured by the number of employees is statistically significant, but there is not continuous trend as in case of age. Entrepreneurs with up to ten employees do not agree with Statement (3) rather than agree. Entrepreneurs with 11-50 employees agree in more cases than disagree. For entrepreneurs with 51-250 employees is difficult to estimate their answer, because probabilities of answers agree (1) and disagree ( -1$)$ are very close. To compare with prediction for Statement (1), where entrepreneurs with up to ten employees disagree with statement that foreign capital is cheaper and therefore they use bank loans, they also disagree with statement that entrepreneur should have more own capital. These two answer are in opposite. The same situation is in case of entrepreneurs with 11-50 
employees, who agree with both statements. So they think that foreign capital is cheaper than own capital, so they use bank loans, but on the other hand, they agree with statement, that entrepreneur should have more own capital. Answers of entrepreneurs with 51-250 employees is difficult to predict.

\section{Discussion}

The results of our analysis revealed several interesting findings. Capital structure of the company clearly related to the duration of the company's business life as well as its size measured by the number of employee. Companies with the longer duration of taking their business prefer more foreign capital to finance their activities. The same result was achieved by tracking of the relationship between company size and foreign capital funding, the larger the company, the more favoured the foreign capital. Reasons are related to financial risks as well as access to foreign sources of financing. This corresponds to the results of the analysis Rahman et al. (2017), who found that not only small but also short-term firms are more vulnerable to limited access to bank finance. That limited access is linked to the risk of default, which also affects interest rates. Kersten et al. (2007) point to this disadvantage in case SMEs and call for solution of this problem by government. For these companies, it is problematic to convince financial institutions about their prosperous business intention, influenced by the innovation cycle, respectively research and development companies with longer return of their investments. The problems with the flexibility of small and mediumsized businesses, the limitations of their growth and the problematic approach to formal sources of funding were pointed out by Beck and Demirguc-Kunt (2006). Their results also confirm the results of our research that there are significant differences between the small and large companies related to the ownership structure of the company. Many small businesses do not currently have their credit policy set up and can not secure a loan. In the case of micro and small businesses, there are limited funding options, in many times only personal savings of individuals. These findings are in line with the findings of Irwin and Scott (2010), who also study educational factors and gender gaps in lending to small businesses in their study. Research was carried out even before the credit crisis, which also raises interest in comparing their results in the current, post-crisis period on the same sample of companies. In case of companies ranked as medium-sized, in our research in the segment of Czech companies, we found evenly distributed managers' preferences when deciding between own and foreign capital. Decisions about capital structure in companies analysed by us are not affected by the business area and localisation. This means that changes in decisions leading to a higher share of the foreign capital are connected with the company's growth, which makes company more flexible and more competitive. The leads to better financial evaluation for external financial institutions (banks, non-bank financial institutions and other institutions providing financial subsidies from EU funds, grant schemes, development national programs, etc.). The economic growth of the company and its positive financial credit also affects business, competitive positions, which is also one of the assessed factors in examining the applicant's economic status of foreign sources of financing. In order to get SMEs on that way, they need support in their start-ups, which is a 
problem in most countries. For this reason, our study is also an appeal for the development of evaluation mechanisms and support schemes based on the assessment of several aspects of the small and medium-sized enterprise business and their potential. These include areas for the provision of socially beneficial activities, innovative companies, research and development centres, and so on.

In our subsequent research, we would like to focus on making more detailed analyses reflecting multiple changes in country financial systems and quantifying their impact on the performance of companies of varying sizes. Then examine the impact of changes in company performance on changes in company capital structure as well as changes in access to external sources of finance. It is also a challenge for us to investigate SME business management, especially in the area of financial flows and working capital, in SME micro-analyses, to identify bottlenecks in SME financing processes and their access to credit. The data we have identified will help us improve the financial management procedures in the SME segment and become more effective and efficient. This would also have a positive effect on several macroeconomic indicators of the country's economy.

\section{Conclusions}

One of the key assumptions for the successful operation of each company in the market economy as well as in the transitive economy is to ensure the optimal volume and structure of the capital that the company uses to cover its business activities. Financial theory gradually developed several models of optimization of the company's capital structure, while maximizing the market value of the company is considered the ultimate criterion of optimality. Many authors examine the adaptability of available models and their employability in corporate practice, but there are few studies to explore the relationship between the capital structure of the firm and its size and stability (expressed as the company's existence). Examining these dependencies will help to clarify how the growth potential of a company is influenced by the tendency for external financing at a given company size. SMEs can possess a great innovation potential that can not be developed without adequate financial support from external funding sources. It is mainly a problem of small and medium-sized companies, with a short existence on the market. This has the effect that many companies with innovative potential will use traditional, existing financial strategies to keep them in a competitive market. This negative effect will affect the intensity of the further development of the SME sector, which has a great importance for the economy of each country, whether in terms of employment, GDP creation or other quantitative economic indicators. These aspects are also connected with the realization of our research in the conditions of SMEs in the Czech Republic. The results of our research show a number of interesting facts. We built five ordinal logistic models, which were applied for prediction of entrepreneur's decision about company's capital structure. Companies with longer duration of taking their business prefer foreign capital rather than their own. Increasing size of the company, measured by the number of employees, leads to rise of the tendency to prefer foreign capital, too. Analysis shown that business area and region, where the company is situated, do not affects decisions about capital structure significantly. According to realised analysis, it is difficult to predict capital structure of the 
medium companies in the Czech Republic because preferences between own capital and foreign capital are distributed equally.

These findings are valuable outputs for policy-makers at both regional and national levels and provide a platform for next research of the financial management of SMEs. Last but not least, based on these results, it is possible to establish economic benchmarking indicators that would allow specific comparative analyses to be made, thus also revealing the relationship between traditional and new determinants, or revealing new ones that influence the decision-making processes of managers in companies. Similarly, these findings can also be valuable to the banking sector, which can get important information about business processes from other sources as well as financial statements from companies. This could also support the development of banking financial consultancy and consultancy activities for SMEs, set up credit rating processes in banks and ultimately support the development of the business environment in the SME segment. In the next research, we would like to analyse effects of changes in country financial systems on capital structure of SMEs. Another research opportunity is analysis of changes in company's performance on its capital structure and credit risk. The main limitation of the paper is the geographical aspect of the dataset which includes only SME's from the Czech Republic. It is also impossible to compare our results with previous studies from different time periods, such as before the financial crisis. Due to to the local dataset, we cannot generalize our results for all SMEs.

\section{Author contributions}

JB prepared the concept of the paper, BG constructed the literature review, PT suggested the methodology, JB and BG carried out the analysis, BG and PT prepared the discussion and the conclusions, JB revised the paper finally. The other remaining activities were done proportionally by all the three authors.

\section{Disclosure statement}

The authors have no competing financial, professional, or personal interests from other parties.

\section{References}

Akhmadeev, B., \& Manakhov, S. (2015). Effective and sustainable cooperation between start-ups, venture investors, and corporations. Journal of Security and Sustainability Issues, 5(2), 269-284. https://doi.org/10.9770/jssi.2015.5.2(12)

Balcerzak, A. P., Kliestik, T., Streimikiene, D., \& Smrčka, L. (2017). Nonparametric approach to measuring efficiency of banking sectors in European Union countries. Acta Polytechnica Hungarica, 14(7), 51-70.

Baños-Caballero, S., García Teruel, P. J., \& Martínez-Solano, P. (2016). Financing of working capital requirement, financial flexibility and SME performance. Journal of Business Economics and Management, 17(6), 1189-1204. https://doi.org/10.3846/16111699.2015.1081272 
Beck, T., \& Demirguc-Kunt, A. (2006). Small and medium-size enterprises: access to finance as a growth constraint. Journal of Banking \& Finance, 30, 2931-2943. https://doi.org/10.1016/j.jbankfin.2006.05.009

Bender, R., \& Grouven, U. (1997). Ordinal logistic regression in medical research. Journal of the Royal College of physicians of London, 31(5), 546-551. http://www.rbsd.de/PDF/olr_mr.pdf

Berger, A. N., \& Udell, G. F. (2002). Small business credit availability and relationship lending: the importance of bank organisational structure. The Economic Journal, 112, F32-F53. https://doi.org/10.1111/1468-0297.00682

Berger, A. N., \& Udell, G. F. (2006). A more complete conceptual framework for SME finance. Journal of Banking \& Finance, 30, 2945-2966. https://doi.org/10.1016/j.jbankfin.2006.05.008

Degryse, H., Goeij, P., \& Kappert, P. (2010). The impact of firm and industry characteristics on small firms' capital structure. Small Business Economics, 38(4), 431-447.

https://doi.org/10.1007/s11187-010-9281-8

Felicio, J. A., \& Galindo Villardón, M. P. (2015). Family characteristics and governance of small and mediun-sized family firms. Journal of Business Economics and Management, 16(6), 1069-1084. https://doi.org/10.3846/16111699.2012.747446

Gavurova, B., Belas, J., Kocisova, K., \& Kliestik, T. (2017). Comparison of selected methods for performance evaluation of Czech and Slovak commercial banks. Journal of Business Economics and Management, 18(5), 852-876. https://doi.org/10.3846/16111699.2017.1371637

Giriūnienè, G., \& Giriūnas, L. (2015). Sustainable development and tax system: it’s impact on entrepreneurship. Journal of Security and Sustainability Issues, 4(3), 233-240.

https://doi.org/10.9770/jssi.2015.4.3(4)

Hackbarth, D., Miao, J., \& Morellec, E. (2006). Capital structure, credit risk, and macroeconomic conditions. Journal of Financial Economics, 82(3), 519-550. https://doi.org/10.1016/j.jineco.2005.10.003

Harc, M. (2014). How does capital structure effect on profability of SME's. Economy of Eastern Croatia yesterday, today, tomorrow, 3, 291-299. Josip Juraj Strossmayer University of Osijek, Faculty of Economics, Croatia.

Irwin, D., \& Scott, J. (2010). Barriers faced by SMEs in raising bank finance. International Journal of Entrepreneurial Behaviour \& Research, 16(3), 245-259. https://doi.org/10.1108/13552551011042816

Kersten, R., Harms, J., Liket, K., \& Maas, K. (2017). Small firms, large impact? A systematic review of the SME finance. World Development, 97, 330-348. https://doi.org/10.1016/j.worlddev.2017.04.012

Kliestik, T., Misankova, M., Valaskova, K., \& Svabova, L. (2018). Bankruptcy prevention: new effort to reflect on legal and social changes. Science and Engineering Ethics, 24(2), 791-803.

Kliestikova, J., Misankova, M., \& Kliestik, T. (2017). Bankruptcy in Slovakia: international comparison of the creditor's position. Oeconomia Copernicana, 8(2), 221-237. https://doi.org/10.24136/oc.v8i2.14

Ključnikov, A., \& Popesko, B. (2017). Export and its financing in the SME Segment. Case study from Slovakia. Journal of Competitiveness, 9(1), 20-35. https://doi.org/10.7441/joc.2017.01.02

Korcsmáros, E., Mura, L., \& Šimonová, M. (2017). Identification of small and medium-sized enterprises development in Slovakia. Journal of Applied Economic Sciences, 12(6), 1702-1712. ISSN 1843-6110.

Kozubíková, L., Homolka, L., \& Kristalas, D. (2017). The effect of business environment and entrepreneurs' gender on perception of financial risk in the SMEs sector. Journal of Competitiveness, 9(1), 36-50. https://doi.org/10.7441/joc.2017.01.03

Kurschus, R. J., Sarapovas, T., \& Pilinkiene, V. (2017). The concept of crisis management by intervention model for SMEs. Inzinerine Ekonomika-Engineering Economics, 28(2), 170-179. https://doi.org/10.5755/j01.ee.28.2.16667

Kralovič, J., \& Vlachynský, K. (2011). Finančný manažment (468p.). Bratislava, Ekonómia. 
Leopoulos, V. N., Kirytopoulos, K. A., \& Malandrakis, C. (2006). Risk management for SMEs: tools to use and how. Production Planning \& Control, 17(3), 322-332. https://doi.org/10.1080/09537280500285136

Mazzarol, T. (2014). Research review: a review of the latest research in the field of small business and entrepreneurship. Financial management in SMEs. Enterprise Research, 21, 2-13. https://doi.org/10.1080/13215906.2014.11082073

Mura, L., Daňová, M., Vavrek, R., \& Dúbravská, M. (2017). Economic freedom - classification of its level and impact on the economic security. AD ALTA-Journal of Interdisciplinary Research, 7(2), 154-157.

Mura, L., Havierniková, K., \& Machová, R. (2017). Empirical results of entrepreneurs' network: case study of Slovakia. Serbian Journal of Management, 12(1), 121-131. https://doi.org/10.5937/sjm12-10418

Rahman, A., Twyeafur Rahman, M., \& Belas, J. (2017). Determinants of SME finance: evidence from three Central European Countries. Review of Economic Perspectives - Národohospodárský obzor, 17(3), 263-285. https://doi.org/10.1515/revecp-2017-0014

Svec, M., \& Madlenak, A. (2017). Legal frameworks for the phygital concept. European Journal of Science and Theology, 13(6), 209-217.

Tvaronavičiene, M. (2016). Start-ups across the EU: if particular tendencies could be trace. Entrepreneurship and Sustainability Issues, 3(3), 290-298. https://doi.org/10.9770/jesi.2016.3.3(6)

Virglerova, Z., Dobes, K., \& Vojtovic, S. (2016). The perception of the states influence on its business environment in the SMEs from Czech Republic. Administratie si Management Public, 14(26), 78-96. Retrieved from http://www.socscistatistics.com/tests/ztest/Default2.aspx

Vlachynský, K., et al. (2009). Podnikové financie (524 p.). Bratislava, Iura Edition.

Vojtovič, S. (2016). The impact of the structural funds on competitiveness of small and medium-sized enterprises. Journal of Competitiveness, 8(4), 30-45. https://doi.org/10.7441/joc.2016.04.02

Warner, P. (2008). Ordinal logistic regression. BMJ Sexual \& Reproductive Health, 34(3), 169-170. http://www.doi.org/10.1783/147118908784734945 